\title{
Effects of Cholecystokinin on Luteinizing Hormone Release from Perifused Hypothalamus-Pituitary in the Castrated Bulls
}

\author{
Shigeto Kanematsu, Narichika Sato, and Tsutomu Hashizume \\ Department of Animal Husbandry, Faculty of Agriculture, \\ Iwate University, Ueda 3, Morioka-shi 020, Japan
}

(Accepted for publication December 14, 1989)

\begin{abstract}
Summary. The effect of cholecystokinin (CCK)-8 was studied on the release of luteinizing hormone ( $\mathrm{LH})$ from perifused medial basal hypothalami (MBH) and/or adenohypophyses of castrated bulls in a sequential double chamber perifusion system. $\mathrm{LH}$ concentrations in the perifusion efflux from the pituitary in series with the hypothalamus decreased significantly $(P<0.05)$ after perifusion of $10^{-8} \mathrm{M}$ CCK as compared with control levels. In the similar perifusion $\mathrm{LH}$ concentrations in the efflux from the pituitary alone decreased significantly $(\mathrm{P}<0.01)$ after perifusion of $10^{-8} \mathrm{M}$ CCK. $10^{-7} \mathrm{M}$ CCK induced neither inhibitory nor stimulatory effects in perifusions of the pituitary in series with the hypothalamus except one fraction. Similarly, $10^{-7} \mathrm{M}$ CCK failed to induce a significant change in LH release in perifusion of the pituitary alone. LH concentrations in the perifusion efflux from pituitary in series with the hypothalamus increased significantly at 50 and $60 \mathrm{~min}$ after the initiation of $10^{-6} \mathrm{M} \mathrm{CCK}$ perifusion as compared with the control level $(\mathrm{P}<0.05)$. LH concentrations in the efflux from the pituitary alone increased significantly $40,50,60$ and $80 \mathrm{~min}$ after the initiation of perifusion with $10^{-6} \mathrm{M}$ CCK.

The results indicate that CCK acts directly on the adenohypophysis to modulate release of LH in cattle.

KEY WORDS: CHOLECYSTOKININ, LH, HYPOTHALAMUS, PITUITARY, CATTLE.
\end{abstract}

Jpn J Anim Reprod 36 54-59, 1990

Immunoreactive cholecystokinin (CCK) and its COOH-terminal octapeptide (CCK-8) have been found in the brains of many animal species (Dockeray, 1976; Weiner et al., 1988) in amounts comparable to those found in the gastrointestinal tract, the traditional site of production for this peptide. Intraventricular injections of CCK induced a suppression of luteinizing hormone (LH) release in ovariectomized rats, whereas CCK failed to induce any LH changes in vitro from incubated male rat pituitaries (Vijayan et al., 1979). These results indicate that CCK inhibits release of $\mathrm{LH}$ by acting through the hypothalamus on the adenohypophysis. In contrary to these results, implantation of powdered CCK-8 into the medial preoptic area (MPO) enhanced the circadian rise in serum $\mathrm{LH}$ in the ovariectomized estrogen-primed rat (Kimura et al., 1983; Hashimoto and Kimura, 1986).

It is of interest to investigate those intricate results as to whether the CCK stimulates or inhibits release of LH, or whether the CCK stimulates or inhibits indirectly through the hypothalamus or directly on the adenohypophysis using superfused castrated bull hypothalamipituitaries. Further, effects of CCK on LH secretion have never been studied in domestic animals. It is also of interest to see the effects of CCK on $\mathrm{LH}$ release in ruminant animals.

\section{Materials and Methods}

Superfusion methods

The medial basal hypothalamus ( $\mathrm{MBH})$ and adenohypophysis were removed from castrated bulls at a local slaughter house within $1 \mathrm{hr}$ of death, and brought to the laboratory in ice cold Krebs-Ringer bicarbonate buffer within $1 \mathrm{hr}$.

The adenohypophysis was cut sagittally into halves before immersion into the buffer. For the perifusion 
medium $10 \mathrm{mM}$ glucose and $100 \mathrm{mg} / \mathrm{l}$ streptomycin sulfate (Meiji Seika Inc., Tokyo) were added to KrebsRinger bicarbonate buffer (118.5 mM NaCl, $4.74 \mathrm{mM}$ $\mathrm{KCl}, 2.54 \mathrm{mM} \mathrm{CaCl}{ }_{2}, 1.18 \mathrm{mM} \mathrm{MgSO}_{4} 1.18 \mathrm{mM}$ $\mathrm{KH}_{2} \mathrm{PO}_{4}, 24.9 \mathrm{mM} \mathrm{NaHCO}_{3}$ ). Bacitracin (Nacarai Tesque Inc., Kyoto, Japan) was added to the medium (modified KRB solution) to prevent peptide degradation $(0.11 \mathrm{mM})$. At the end of the perifusion the tissues were tested for viability by perifusing a medium enriched in $\mathrm{K}^{+}\left(123.2 \mathrm{mM} \mathrm{KCl}, 2.54 \mathrm{mM} \mathrm{CaCl}_{2}, 1.18\right.$ $\mathrm{mM} \mathrm{MgSO}_{4}, \quad 1.18 \mathrm{mM} \quad \mathrm{KH}_{2} \mathrm{PO}_{4}$ and $24.9 \mathrm{mM}$ $\mathrm{NaHCO}_{3}$ ). The perifusion system consisted of a serial double chamber superfusion system (modified from Miyake and Yen, 1981; Zolman and Convey, 1972): the first chamber was made from a $3 \mathrm{ml}$ polyethylene disposable syringe; the second chamber was made from a $1 \mathrm{ml}$ syringe. In this system, the effluent from the first chamber perifused the second chamber by means of a peristaltic pump (Minipuls-2, GILSON) at a flow rate of $18 \mathrm{ml} / \mathrm{hr}$. Both the medium delivered and that contained in the two chambers were saturated with a mixture of $\mathrm{O}_{2} / \mathrm{CO}_{2}$ gas $(95 / 5 \%)$. The chambers were maintained at $38^{\circ} \mathrm{C}$ in a water bath. The medial basal hypothalamic tissue prepared for perifusion was limited dorsally $3 \mathrm{~mm}$ deep, frontally by the caudal border of the optic chiasm, laterally by $1 \mathrm{~mm}$ lateral to the tuber cinereum, and caudally by the rostral border of the mamillary body. The adenohypophysial tissues used for perifusion were five pieces of $1.5 \mathrm{~mm}$ cubes from a central part (mainly from the zona tuberalis) of the adenohypophysis. The mean wet weights and standard errors of the $\mathrm{MBH}$ and pituitary tissues after perifusion in 10 experiments were $712.9 \pm 44.3 \mathrm{mg}$ and $44.9 \pm 4.6$ $\mathrm{mg}$, respectively. The $\mathrm{MBH}$ was placed in the first chamber, and the pituitary tissues were in the second chamber after repeated rinse of the tissues. The effluent from the second chamber was collected in $3 \mathrm{ml}$ fractions at $10 \mathrm{~min}$ intervals. The flow rate used was 18 $\mathrm{ml} / \mathrm{hr}$. The MBH was placed in the first $1.7 \mathrm{ml}$ chamber, and the five pieces of pituitary tissues in the second 0.5 ml chamber. In other studies, the first chamber was kept empty, and the pituitary tissues were placed alone in the corresponding chamber of the series. After tissues were placed in the appropriate chambers, the system was equilibrated for $3 \mathrm{hr}$ before initiating to collect samples. Six samples of $3 \mathrm{ml}$ each were collected over a period of $1 \mathrm{hr}$ as controls, and then $10^{-8} \mathrm{M}, 10^{-7} \mathrm{M}$ or $10^{-6} \mathrm{M}$ CCK-8 (Peptide Institute Inc. Osaka, Japan) in the modified KRB solution were perifused for $100 \mathrm{~min}$. After the perifusion of CCK-8, the tissues were perifused for $100 \mathrm{~min}$ with the modified KRB solution, which was followed by a $\mathrm{K}^{+}$solution for $30 \mathrm{~min}$. Collected fractions were stored at $-20^{\circ} \mathrm{C}$ until assayed.

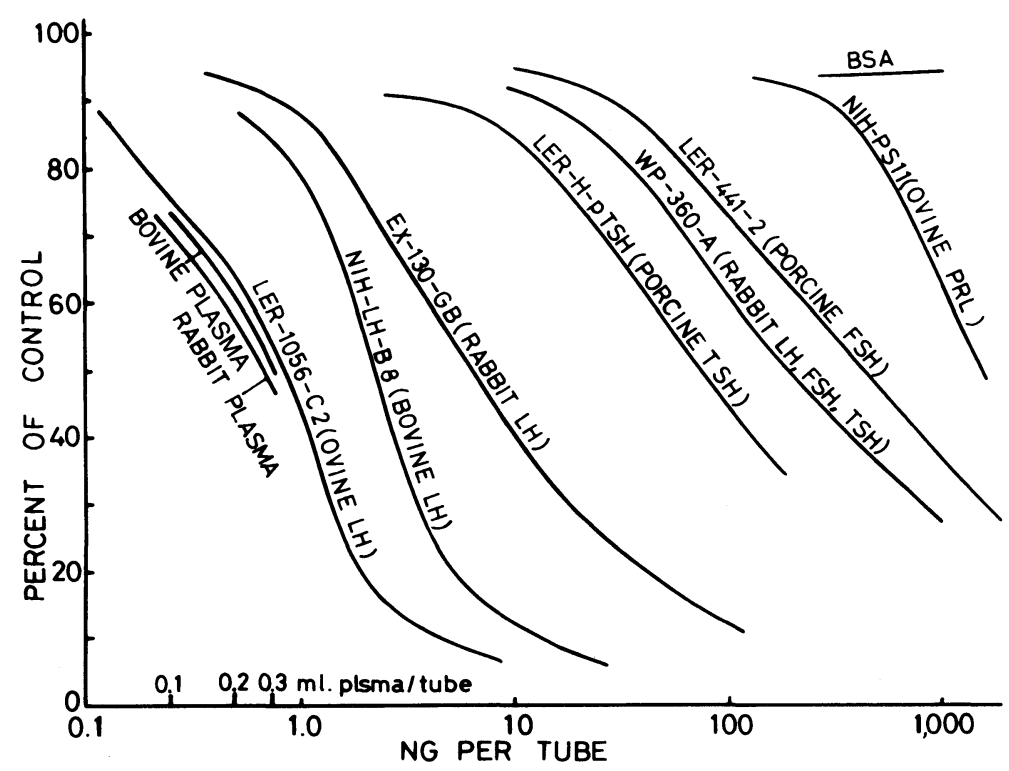

Fig. 1. Dose-response curves for purified pituitary preparations and serum with use of ovine $\mathrm{LH}$ antiserum. 
Radioimmunoassays and antiserum to $\mathrm{LH}$

LH in these fractions were measured by a double antibody radioimmunoassary (Scaramuzzi et al., 1972). Polyethylene glycol 6,000 (mol. wt., 7,500) was added to the anti-guinea pig gamma globulin serum to insure a complete precipitation with the dilution rate of $1 \%$ polyethylene glycol at the final incubation.

For a generation of an antiserum to $\mathrm{LH}$, four guinea pigs were immunized with sc injections of $0.91 \mathrm{mg}$ of NIH-LH-S1 8 emulsified in $2 \mathrm{ml}$ of a $1 / 1$ mixture of Freund's complete adjuvant and saline. This procedure was repeated several times in addition to a booster iv injection. On the day 135 the serum obtained from a female contained the best antibody as determined by testing of titers, specificity and affinity of serum samples.

Dose-response curves demonstrating the decrease in amount of antibody-bound ovine $\mathrm{LH}^{-125}$ I which occurred with increasing levels of pituitary hormones and bovine and rabbit plasma are shown in Fig. 1. The region where the quantity of ovine $\mathrm{LH}^{125} \mathrm{I}$ bound was equal to 20-85\% of that bound in PBS-BSA control tubes was used for estimating relative potencies. In this area the curves for all preparations tested were parallel each other in slope. Percentages of cross reaction from bovine LH (NIH-LH-B8) with the rabbit LH (Papkoff, Ex-130-GB), porcine TSH (LER-H-p TSH), crude rabbit pituitary fraction (Parlow, WP-360-A), porcine FSH (LER-441-2) and ovine PRL (NIH-PS 11) were $33.8,2.9,1.2,0.5$ and $0.2 \%$ respectively. Percentages of cross reaction from the rabbit LH (Papkoff, EX-130GB) with the porcine TSH (LER-H-p TSH), porcine FSH (LER-441-2) and ovine PRL (NIH-PS 1 1) were 8.7, 1.5 , and $0.4 \%$ respectively. NIH-LH-S18 contained 0.033 USP units $\mathrm{TSH} / \mathrm{mg}$ and less than $0.050 \mathrm{NIH}-$ FSH-S1 units/mg.

The reference standard used was NIH-LH-B8, which contained less than 0.050 NIH-FSH-Sl units/mg and $0.19 \mathrm{USP}$ units $\mathrm{TSH} / \mathrm{mg}$. The mean potency of $\mathrm{NIH}$ LH-B 8 was 1.03 NIH-LH-Sl units/mg. The minimum detectable $\mathrm{LH}$ concentration in 17 RIAs was $0.200 \pm$ $0.33 \mathrm{ng} / \mathrm{tube}$. The within-and between-assay coefficient of variation in the present assays were $4.1 \%$ and $12.5 \%$ respectively.

Mean and standard error of LH peak values during LH surge in 36 Japanese Black cows was $51.8 \pm 2.9$ $\mathrm{ng} / \mathrm{ml}$ as blood sampels were collected every $2 \mathrm{hr}$ during estrus, while $\mathrm{LH}$ values during early proestrus were $2.65 \pm 0.16 \mathrm{ng} / \mathrm{ml}$ in 36 cows. The mean LH concentra-

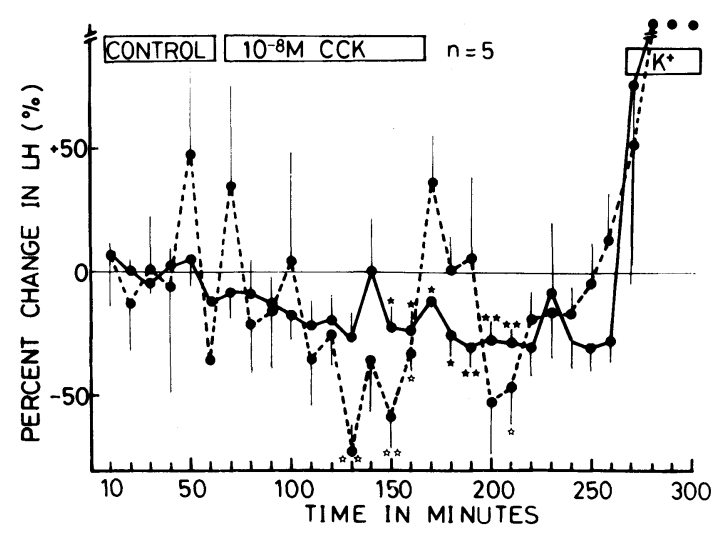

Fig. 2. LH changes in the effluents from the pituitary in series with the hypothalamus (solid line) or pituitary alone (broken line) with the meduim containing $10^{-8} \mathrm{M}$ CCK for $100 \mathrm{~min}$. The mean $\mathrm{LH}$ concentration of 6 fractions collected during $1 \mathrm{hr}$ before CCK perifusion was taken as percentage changes from the control value in each group. Note that the $10^{-8} \mathrm{M}$ CCK perifusion decreased LH concentrations. Each points represent mean and SEM. Asterisks represent a significant change from the control level (*, $\mathrm{P}<0.05$; **, $\mathrm{P}<0.01$ ). Solid stars: hypothalamus-pituitary perifusion group; open stars: pituitary perifusion alone.

tions of the resting level in the perifusion efflux of all experiments was $25.0 \pm 2.6 \mathrm{ng} / \mathrm{ml}$, while the treatments with a high $\mathrm{K}^{+}$increased the $\mathrm{LH}$ concentrations to $180.0 \pm 2.5 \mathrm{ng} / \mathrm{ml}$.

\section{Statistical analysis}

Data are expressed as means \pm SEM. Statistical analyses were performed with the Student's t-test. The parallelism of slopes between dose-response curves of the standard and other hormones were calculated based on formulas of Bliss(1952). Cross-reactions were expressed in terms of the mass of unlabelled compounds which were required to displace $50 \%$ of the labelled antigen.

Percent of cross reaction $=x / y \times 100$, where $x=$ mass of antigen at $50 \%$ displacement, $y=$ mass of crossreacting compound at $50 \%$ displacement.

\section{Results}

As shown in the Fig. 2, LH concentrations in the perifusion efflux from the pituitary in series with the hypothalamus declined progressively and the decreased levels become significant $(\mathrm{P}<0.05)$ at 90 and $100 \mathrm{~min}$ after the initiation of perifusion of $10^{-8} \mathrm{M} \mathrm{CCK}$ as 


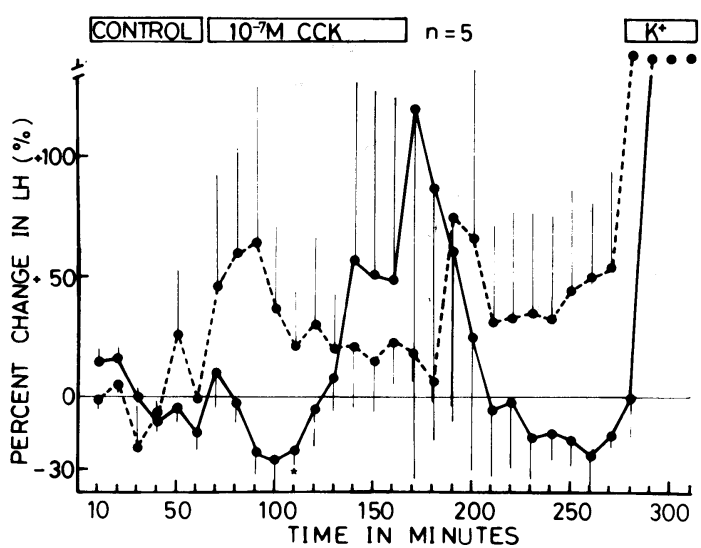

Fig. 3. LH changes in the effluents from the pituitary in series with the hypothalamus (solid line) or pituitary alone (broken line) with the medium containing $10^{-7} \mathrm{M}$ CCK for $100 \mathrm{~min}$. See also Fig. 2 for explanations of the figure.

compared with control levels. This significant reduction in $\mathrm{LH}$ concentrations induced by $\mathrm{CCK}$ perifusions were continuously effective even after cessation of CCK perifusions for $50 \mathrm{~min}$ (after 10 and $20 \mathrm{~min}$ : $\mathrm{P}<0.05$; after 30, 40, and $50 \mathrm{~min}: \mathrm{P}<0.01)$. In the similar perifusion LH concentrations in the efflux from the pituitary alone have shown a progressive decline and the decrease become significant after 70 and $90 \mathrm{~min}$ $(\mathrm{P}<0.01)$ and after $100 \mathrm{~min}(\mathrm{P}<0.05)$. This reduction in LH concentration induced by CCK was significant $(\mathrm{P}<0.05) 50 \mathrm{~min}$ after the cessation of CCK perifusion. After high $\mathrm{K}^{+}$treatments, the $\mathrm{LH}$ levels in the efflux increased sevenfold from the resting levels.

$10^{-7} \mathrm{M}$ CCK induced neither inhibitory nor stimulatory effects on $\mathrm{LH}$ concentrations in the perifusion efflux from the pituitary in series with the hypothalamus except one fraction at $50 \mathrm{~min}$ after the initiation of perifusion with $10^{-7} \mathrm{M} \mathrm{CCK}$ (Fig. 3). Initial $\mathrm{LH}$ rise after CCK perifusion, however, was observed in 3 out of 5 experiments in the pituitary perifusion in series with the hypothalamus. $10^{-7} \mathrm{M}$ CCK induced $\mathrm{LH}$ rise only 2 out of 5 experiments, when the pituitary was perifused alone.

As shown in Fig. 4, LH concentrations in the perifusion efflux from the pituitary in series with the hypothalamus increased significantly 50 and $60 \mathrm{~min}$ after the initiation of $10^{-6} \mathrm{M} \mathrm{CCK}$ as compared with the control level $(\mathrm{P}<0.05)$. LH concentrations in the efflux from the pituitary alone increased significantly $(\mathrm{P}<0.05) 40,50,60$ and $80 \mathrm{~min}$ after the initiation of

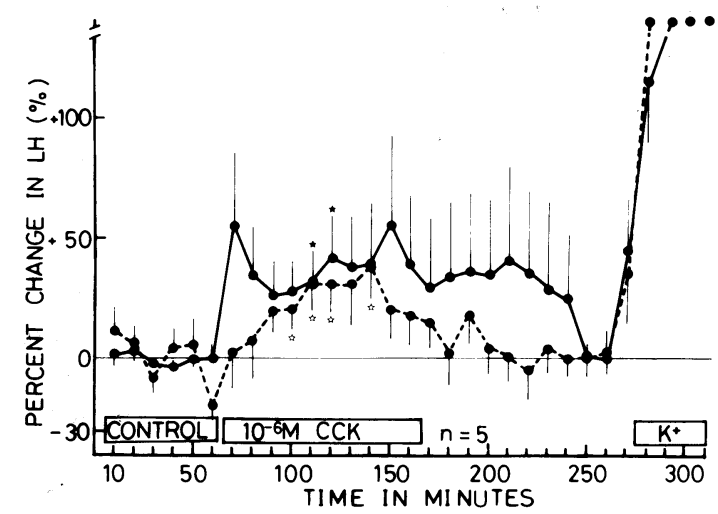

Fig. 4. LH changes in the effluents from the pituitary in series with the hypothalamus (solid line) or pituitary alone (broken line) with the medium containing $10^{-6} \mathrm{M}$ CCK for $100 \mathrm{~min}$. Note that the $10^{-6} \mathrm{M}$ CCK elevated LH concentration significantly in the effluents of the two groups. See also Fig. 2 for explanations of the figure.

perifusion with $10^{-6} \mathrm{M}$ CCK.

\section{Discussion}

To our knowledge, the present study in the first demonstration of the effects of CCK on LH release in cattle. In the present study CCK inhibited release of LH from bovine pituitaries at a dose level of $10^{-8} \mathrm{M}$, regardless of whether the pituitary tissues were perifused with or without the hypothalamus. The inhibitory effect of CCK on LH release has been shown using an intraventricular injection method in the rat (Vijayan $e t$ al., 1979). They failed to show a significant effect of CCK on LH levels in cultured pituitary cells. From these results they concluded that the CCK inhibited pitiutary LH release acting via the hypothalamus. Frequent samplings in the superfusion system of the present study were able to demonstrate an inhibitory effect of CCK on pituitary LH release acting directly on the adenohypophysis. This direct inhibition by $10^{-8} \mathrm{M} \mathrm{CCK}$ of the pituitary from releasing $\mathrm{LH}$ could be interpreted as a physiologic effect.

On the contrary to an inhibitory effect of $10^{-8} \mathrm{M} \mathrm{CCK}$ on pituitary $\mathrm{LH}$ release, $10^{-6} \mathrm{M}$ CCK stimulated $\mathrm{LH}$ release. Kimura et al. (1983) reported that implantation of powdered CCK into the medial preoptic area induced the elevation of $\mathrm{LH}$ values in ovariectomized estrogen-primed rats. This increase in LH was blocked by a dopamine receptor blocker, pimozide(Hashimoto 
and Kimura 1986). These results were at variance with those reported by Vijayan et al. (1979) who found the inhibitory effect of CCK on the pituitary $\mathrm{LH}$ release in an indirect effect through the hypothalamus. The present results in $10^{-6} \mathrm{M} \mathrm{CCK}$ perifusion of the pituitary with the $\mathrm{MBH}$ tissues were in agreement with the earlier observations reported by Kimura et al.(1983). They implanted a powdered CCK directly in the brain tissue. Therefore, an extremely high concentration of CCK might have affected tissues around the site of implantation on the MPO. It is not known so far the implanted CCK had diffused or picked up to the pituitary portal system. Yet water soluble CCK might have reached to a considerable distance, although they could claim that the implanted CCK in the MPO enhanced $\mathrm{LH}$ release in vivo on the brain tissue. In the present study the increased release of $\mathrm{LH}$ induced by $10^{-6} \mathrm{M}$ CCK could be interpreted as a pharmacologic effect; and this stimulative effect might not be unlike that of Kimura et al. (1983). The stimulating effects of $10^{-6} \mathrm{M}$ CCK on $\mathrm{LH}$ release, however, were effective regardless of whether the adenohypophysial tissues were perifused with or without the MBH tissues. While C.CK was found to have a biphasic effect on $\mathrm{LH}$ release depending on its concentrations, perifusions of the pituitary-hypothalamus or pituitary alone with an intermediate dose level of CCK $\left(10^{-7} \mathrm{M}\right)$ induced neither inhibitory nor stimulatory effects on $\mathrm{LH}$ release except one fraction. The reason remains undetermined why $10^{-7} \mathrm{M}$ CCK failed to show a significant effect on pituitary $\mathrm{LH}$ release. It has been reported that the major hypothalamic source of CCK is from neurons of the paraventricular nucleus (Beinfeld et al., 1981). Brain CCK receptors show high densities in the ventromedial hypothalamic nucleus, supraoptic and paraventricular nuclei, and also in the pituitary (Day et al., 1986). The inhibition of LH release after intraventricular injection of CCK (Vijayan et al., 1979) and the stimulatory effect of hypothalamic implanted CCK on LH release (Kimura et al., 1983) in rats were consistent with the present results, which showed an inhibitory effect of $10^{-8} \mathrm{M}$ CCK on pituitary $\mathrm{LH}$ release and a stimulatory effect of $10^{-6} \mathrm{M}$ CCK on $\mathrm{LH}$ release in perifused adenohypophysial tissues in vitro in cattle.

\section{Acknowledgments}

We are indebted to Dr. Leo Reichert Jr., Emory University (now in the Albany Medical College) and
NIAMD for their kind supply of purified pituitary hormone preparations and to Dr.H.Papkoff, University of California, San Francisco, Dr. A. V. Parlow, Harbor General Hospital, for rabbit pituitary preparations. We wish to thank Dr. K. Wakabayashi, Institute of Endocrinology, Gunma University for his kind supply of anti-guinea pig gamma globulin serum. The present work was supproted by a Grant-in-Aid for Scientific Research No. 62480076 from the Ministry of Education, Science and Culture.

\section{References}

Beinfeld MC, Meyer DK, Eskay RL, Jensen RT, Brownstein MJ (1981) The distribution of cholecystokinin immunoreactivity in the central nervous system of the rat as determined by radioimmunoassay. Brain Res 212 : 51-57.

Bliss CI (1952) The Statistics of Bioassay. Academic Press, New York.

Day NC, Hall MD, Clark CR, Hughes J (1986) High concentrations of cholecystokinin receptor binding sites in the ventromedial hypothalamus. Neuropeptides 8: 1-18.

Dockeray GJ (1976) Immunochemical evidence of cholecystokinin-like peptides in brain. Nature 264: 568-570.

Greenwood FC, Hunter WM, Glover JS (1963) The preparation of ${ }^{131}$ I labelled human growth hormone of high specific radioactivity. Biochem $J$ 89: 114-123.

Hashimoto R, Kimura F (1986) Inhibition of gonadotropin secretion induced by cholecystokinin implants in the medial preoptic area by the dopamine receptor blocker, pimozide, in the rat. Neuroendocrinology 42: 32-37.

Kimura F, Hashimoto R, Kawakami M (1983) The stimulatory effect of cholecystokinin implanted in the medial preoptic area on luteinizing hormone secretion in the ovariectomized estrogen primed rat. Endocrinol Japon 30: 305-309.

Miyake A, Yen SSC (1981) Direct in vitro stimulation of pituitary $\mathrm{LH}$ release by alpha melanocyte stimulating hormone. Life Sci 29: 2637-2640.

Scaramuzzi RJ, Blake CA, Papkoff H, Hilliard J, Sawyer CH (1972) Radioimmunoassay of rabbit luteinizing hormone: serum levels during various reproductive states. Endocrinology 90: 1285-1291.

Vijayan E, Samson WK, McCann SM (1979) In vivo and in vitro effects of cholecystokinin on gonadotropin, prolactin, growth hormone and thyrotropin release in the rat. Brain Res 172: 295-302.

Weiner RI, Findell PR, Kordon C (1988) Role of classic and peptide neuromediators in the neuroendocrine regulation of LH and prolactin. In: The Physiology of Reproduction Vol. 1 (Knobil E, Neill JD eds.), Raven Press, New York. 
Zolman J, Convey EM (1972) Bovine pituitary LH and prolactin release during superfusion in vitro. Pro Soc Exp Biol Med 140: 194-198.

\section{去勢牛の視床下部一下垂体の in vitro 灌流系における 黄体形成ホルモン放出に及ぼすコレシストキニンの効果}

兼松 重任・佐藤 尚親・橋爪力

岩手大学農学部畜産学科家畜繁殖学講座

\begin{abstract}
コレシストキニン $(\mathrm{CCK})$ が家音の黄体形成ホルモ ン（LH）の放出に与える影響を検討した。屠場でえた 去勢牛の視床下部一下垂体組織を in vitro の灌流系に置 き, CCK を灌流し, 灌流液中の LH をラジオイムノア ッセイで測定した。灌流装置には二室があり, 第一室に は視床下部の内側底部組織を入れ，そこを流れた液が下 垂体組織をいれた第二室に流れるようにした（連続）。 そのほか下垂体のみの灌流も同時に行った（単独）。灌
\end{abstract}

流液は修正クレブス液を用い $38^{\circ} \mathrm{C}$ に保った。 $10^{-8} \mathrm{M}$ の CCK は連続・単独灌流とも有意に灌流液中の LH 濃度 を低下させた $(\mathrm{P}<0.05 \cdot \mathrm{P}<0.01)$ 。これに対して, $10^{-6} \mathrm{M}$ の CCK は連続・単独灌流とも逆に有意に LH 濃度を増加させた $(\mathrm{P}<0.05)$ 。 $10^{-7} \mathrm{M}$ の $\mathrm{CCK}$ では一 定した変化は得られなかった。以上のことから, CCK は牛の腺下垂体に直接作用して LH の放出を調整するこ とが示唆された。 